\section{A hazai COVID-19-járvány tanulságai 2020 június végén}

\author{
„Ha egyértelmü, hogy a célt nem tudod \\ elérni, ne a célon, hanem a cselekvési \\ lépéseiden változtass." (Confucius)
}

Az emberiség által megtapasztalt utolsó, pusztító légúti járványban (spanyolnátha), 100 éve, az elhunytak számát 20-50 millióra becsülték [1]. Ezt az influenzavírus HINl variánsa okozta, melyről pontosan nem tudjuk, hogy honnan érkezett, egyes feltételezések szerint Tibetből, de az bizonyos, hogy Európába az amerikai katonák hurcolták be a Nagy Háború idején. Riadalmat okozott, hogy 2009-ben ugyanennek a vírusnak (HINl) a visszatérését észlelték (sertésinfluenza, swine flu), és az utólag elvégzett szeroepidemiológiai vizsgálatok szerint úgy tudjuk, hogy a világ népességének 11-21\%-a megfertőződött, és a halálesetek számát 150-575 ezerre becsülték.

A WHO szerint a szezonális influenza éves halálozási száma átlagosan 291243 645832 a világon [2]. A 2018/19-es szezonban az USA-ban (CDC) 35,5 millió megbetegedés történt, 490 600-an kerültek kórházba és 34 200-an haltak meg az influenza következtében [3].

Az elmúlt évtizedekben számos más influenza-variáns elterjedését is észleltük, melyek szezonális influenza formájában jelentkeztek (például avian flu, Hong Kong, H5N1, 1997, H9N2, 1999), de súlyos betegséget okozó koronavirus-járvány jelent meg 2003-ban, melyet SARS-nak neveztek el (Severe Acute Respiratory Syndrome, SARS-CoV-1) [4]. A járvány, amilyen hirtelen indult és terjedt, összességében mindössze kb. 8000 megbetegedést okozott a világban és $10 \%$-os letalitással járt. A vírus, a kutatások szerint, az ún. civet macskákról terjedt emberekre a piacon árusított állatokról, azok elfogyasztásával [5]. A gyors elterjedést követően sehol nem alakultak ki a jelenlegi COVID19-hez hasonló nagyobb járványok, és a vírus, eddig megmagyarázhatatlan okból, „eltûnt”, később már nem tudták azonosítani.

A 2012-ben feltűnt MERS (MiddleEast Resporatory Syndrome), melyröl kiderült, hogy egy tevékról emberre terjedó koronavírus, csak kisebb epidémiát okozott, de igen magas letalitással járt (3237\%). Megjelenésétől mostanáig kb. 2500 megbetegedést azonosítottak és kb. 800- an haltak meg. Nagyobb járványok nem alakultak ki, mert a vírus emberről emberre történő terjedési képessége igen mérsékelt [6].

A most már remélhetőleg lecsengőben levő járvány az egészségügyet, az ország lakosságát és az intézkedő hatóságokat is komoly stressz-tesztnek vetette alá, amire az elmúlt évtizedekben, de akár az elmúlt 100 évben, nem volt példa.

A SARS-CoV-1 és a jelenlegi SARSCoV-2 80\%-os hasonlóságot mutat, amely, ha figyelembe vesszük, hogy a csimpánzok és emberek között 98\%-os genetikai hasonlóság van, nem igazán nagy. Közös gazdaszervezetüknek a denevéreket tekintik. Ellentétben a korábbi koronavírusokkal, a jelenlegi az egész világon kiterjedt járványokat okozott, a megfertőzöttek száma meghaladta a nyolcmilliót, az elhunytak száma közel 460 ezer [7]. A letalitási arány (június 14.) 5,59\%, Magyarországon a fertőzöttek száma meghaladta a négyezret és a halottak száma közelíti a 600-at, ami a június 14-i állás szerint 13,7\%-os letalitást jelent, de fontos annak ismerete, hogy ebbe a csoportba soroltak mindenkit, aki valamilyen más, súlyos alapbetegségben szenvedett és a vírussal is fertőződött [8]. Más országokban csak azokat számolták, akiknek a vírusfertőzésen kívül más alapbetegsége nem volt (Szlovákia).

Az egyes országok a járvány megjelenésére igen eltérően reagáltak. Az első igazolt eseteket követően röviddel bevezetett megszorításoktól várható volt a járvány alacsony szinten tartása, mint Magyarországon, de például Ukrajnában, a korán bevezetett megszorítások ellenére is komoly járvány alakult ki [9]. Svédországban úgy gondolták, hogy megvárják az ún. nyáj-immunitás kialakulását, mely azt eredményezte, hogy sokkal több fertőzés alakult ki, mint a többi skandináv országban. Egyes ázsiai országokban (Dél-Korea, Szingapúr, Japán) a veszélyeztetett lakosságcsoportok kiterjedt szürésével hatékonyan védekeztek a járvány terjedése ellen, így csak részleges megszorításokat kellett bevezetni (Japán). Afrikában súlyos zavargásokhoz vezettek a gyakran indokolatlanul elrendelt megszorítások, és ennek következtében a halálos áldozatok száma nagyobb volt, mint a fertôzés miatt elhunytaké.

A járvány eddigi lefolyásából világosan kiderül, hogy Európában, a korábbi „,szocialista" országokban több mint tízszeresen alacsonyabb volt a fertőzöttek száma, mint a nyugat-európai országokban, mely különbségeket nem lehet kizárólag a korán bevezetett megszorító intézkedésekkel megmagyarázni. Ez a különbség jól kimutatható Németországban is, ahol a korábbi NDK területén sokkal alacsonyabb volt a fertőzöttek aránya [10]. Joggal merül fel az a szempont, hogy ezekben az országokban, a volt NDK-val együtt, a lakosság átoltottsága meghaladja a 95\%-ot, ami felveti azt a lehetőséget, hogy ez a körülmény a lakosság nagyobb ellenállóképességét eredményezte. A járvány során felmerült hipotézisként, hogy a kötelező BCG-vakcinációnak szerepe lehet a COVID-19-cel szembeni védettségnek [11], néhány országban (Hollandia, Ausztrália) még az egészségügyi személyzet vakcinációját is fontolóra vették. A vakcinációs védettség koncepciójának a tudományos alapja lehet, hogy a koronavírusok tüskéiben jelen levő fehérjék és a pl. kanyaró (morbilli) vírus egyes komponensei hasonlóságot mutatnak, ezért a MMR-vakcina jelenthet bizonyos védettséget a koronavírus-fertőzéssel szemben [12].

Az érintett országokban, így hazánkban is, hamarosan a politikai viták középpontjába kerülttek a járvánnyal kapcsolatos intézkedések elrendelése, vagy ezek hiánya, melynek a jellegébe, részleteibe nem érdemes belemenni, de biztosan nem segítette a járvány elleni védekezést, és a tanulságokat mindenképpen le kell vonni. A járványügyi adatok kommunikációja szakmai szempontból vitatható volt. Annak az orvosi evidenciának a figyelmen kívül hagyása, hogy a „fertőzött” nem azonos a fertőzés következtében kialakult betegséggel és ezen belül a kórházi kezeléssel, vélhetően befolyásolta a számításokat. A fertőzöttek megjelenésének kezdetén a karantén idejét is kórházban kellett, teljesen indokolatlanul, eltölteni a tünetmentes fertőzötteknek. Vita bontakozott ki arról és politikai toposszá vált, hogy mennyit, kiket és hogyan kell tesztelni. Megdöbbenést keltett, hogy a tanácsadók olyan méretű hazai járványt vizionáltak, melyhez 14 ezer lélegeztetőgép és több tízezer kórházi ágy kiürítése szükségeltetik, a hirtelen felépült és kijelölt járványkórházzal együtt. Az is elhangzott a híradásokban, hogy kb. negyedmillió ember „etetésére” kell készülni, ami félelmetes nagyságrend és olyan arányú járványt tételezett fel, mint ami a nagy nyugat-európai országokban együttesen volt. Figyelembe véve azt a körülményt, hogy a tünetes fertőzöttek kb. 20\%-a igényel kórházi kezelést és a hazai adatokból látható, hogy ezeknek az 5-7\%-a szorul gépi lélegeztetésre, akkor, ha 10 ezer lélegeztető- 
gép együttes múködését tételezzük fel, amire személyzet sincs, akkor kb. 200-142 ezer kórházban ápolt fekvóbeteg lenne a hazai ellátóhelyeken, és a tünetes fertőzöttek száma 800 ezer és 1 millió körülire lenne tehető. Mindez, szerencsére, nem következett be, de mindenképpen vizsgálatot érdemelne, hogy a valóság és az elképzelt scenárió között miért volt ilyen különbség. Kétségtelen tény, hogy a különböző kormányzati szervek minden erőfeszítést megtettek, hogy akár egy ilyen méretû nyomás esetén is megteremtsék a háttérfeltételeket.

A COVID-19-kezeléssel kapcsolatban megjelent számos közlemény ellenére, a kezdeti, biztató megfigyelések sem tudtak azonosítani a kipróbált gyógyszerek közül egyet sem, ami kelló hatékonysággal vethetô be a vírus ellen. A klorokin-foszfát nem rendelkezik antivirális hatással, de gátolja a COVID-19-nek a sejtekbe történő bejutását, és az esetek 10\%-ban mellékhatások kialakulását észlelték, de a vírusürítés időtartama lerövidült $[13,14]$.

$\mathrm{Az}$ ismert antivirális hatású gyógyszerek közül a Remdesivir kipróbálása biztató eredményeket mutatott [15], és a reconvalescens plasma alkalmazása, melyet már a 100 évvel ezelőtti spanyolnáthánál, valamint a Lassa-láznál és Ebolánál kipróbáltak, hatékonynak bizonyult, melyet sikerrel alkalmaztunk itthon is [16]. Voltak biztató hazai próbálkozások anticitokin-terápiával kapcsolatosan is [17].

A hatékony és a kereskedelemben elérhetô oltóanyag bevezetésére, az optimista nyilatkozatokkal ellentétben, még jó darabig várni kell, mivel egy ilyen vakcina elóállítása (hatékonysági, biztonsági vizsgálatok, esetleges mellékhatások megállapítása, stb.) éveket vesz igénybe. A már régóta megismert (SARS, 2003 és MERS, 2012) koronavírusokkal szemben sincs még elérhető vakcina.

A járvány múlásával el kell gondolkodni azon a tényen, hogy infekciós eredetú megbetegedések még mindig vannak, sőt hasonló járványok is várhatóak még, miközben az infekciós eredetű betegségek oktatása igen alacsony óraszámban történik, és van olyan egyetem, ahol ilyen tantárgy nincs is. Az is figyelemre méltó, hogy trópusi betegségek oktatása csak ún. „speciális kollégium" szinten történik, ami azt jelenti, hogy a trópusi országokból érkezó hallgatók nem is hallanak azokról a betegségekről, amelyekkel otthon esetleg majd találkoznak. Az infektológiai osztályokat régen úgy alakították ki, hogy az izolációs képességeknek megfeleljenek, mert ez az alapja a fertőző betegek ellátásának. Az újonnan épült járványkórház (Kiskunhalas) minden ilyen követelménynek megfelel, és a nagyobb ellátóhelyeken (például egyetemi városokban) célszerű lenne ilyen létesítményeket megépíteni. Példamutató, hogy a SZOTE önálló infektológiai tanszék, intézet létesítésére törekszik, és ahogyan ez a Debreceni Egyetem kórházi integrációját követően megvalósult.

Ma már teljesen világos, hogy az orvosi szakma egy olyan hivatás, amely vonzerejének megteremtésében a graduális képzésnek, a minták nyújtásának alapvető szerepe van, és ez különösen igaz a hiányszakmákra. A járvány most különösen három hiányszakma - infektológia, sürgősségi betegellátás, intenzív terápia - ellátási tűréshatárait feszegette. Egyben rámutatott arra is, hogy a graduális képzőhelyek óraszámai és ráfordított gyakorlati képzései mennyire elégtelenek ahhoz, hogy egy infektológiai krízishelyzetben a már végzett általános orvosok megfelelő gyakorlati ismerettel és elméleti tudással rendelkezzenek. Azt gondoljuk, hogy az orvosképző helyeken zajló curriculum-reform során a radikális változtatást és gyakorlati szempontból hasznosítható tudást sürgető tábor most hathatós munícióhoz jutott a járvány krízishelyzetében. $\mathrm{Az}$ ismétlődő és egyre hevesebbé váló járványok arra is felhívják a figyelmet, hogy az elkövetkező időszak fontos egészségpolitikai feladata lesz az infektológiai ellátás szisztematikus és rendszerszintű támogatása. Ennek egyik eleme az infektológia, mint pálya vonzóvá tétele mind a szakmai háttér, mind pedig anyagi megbecsültség vonatkozásában. Egy következő lépés a hazai infektológiai ellátás rendszerének áttekintése és lakosságarányos ellátási gócpontok létrehozása, valamint szakmai megerősítése kell legyen. Az intenzív és sürgősségi ellátás vonatkozásában ez a járvány sajnos hasonló segélykiáltásokat hozott a felszínre. A szakma régóta sürgeti a hazai intenzív ellátás koncepcionális átalakítását [18]. Az egyébként már elkezdett szakmai súlypont-áthelyezések és a szakma humánerőforrás- és múszeres megerősítése kétségtelenül elkezdődött, de - ahogy a járvány most felszínre is hozta - még rengeteg a teendő

Évek óta folyamatosan zajlik egy bizonyos vita az egészségügy menedzsment-oldala és a szakmai oldal között a szakmai minimumfeltételek átdolgozásáról. Ez egy olyan kötélhúzás, amelyben az egyik fél a költségfókuszú csökkentés, a másik pedig a szakmai alapú elvárások mentén a legroszszabb forgatókönyv esetén is helytállni képes ellátásnak megfelelő feltételrendszer biztosítása felé igyekszik a súlypontot elmozdítani. A járvány kihívásainak jelentkezésekor vált világossá, hogy bizonyos ki- emelt szakmákban (és a sürgősségi és az intenzív ellátás ezek közé tartozik) nem lehet túlzónak nevezni azt, ha az ellátás feltételeinek meghatározásakor a békeidőben is a "worst case scenario" elveit követjük, hiszen ebben van benne annak lehetősége, hogy egy felfokozott kihívás esetén is meg tudjon felelni az intenzív ellátás a vele szemben támasztott elvárásoknak.

Az ország különböző tényezők kedvező együtt állása révén esélyt kapott a járványhelyzet kezelésére, és az első hullám esetén ez sikeresnek bizonyult. A kezdeti hetek izgalmai és gyors, a helyzet által kikényszerített akciói arra is rámutattak, hogy legalább ellátási régiónként ki kell alakítani és képzésekkel, valamint időnkénti gyakorlatokkal folyamatosan karban kell tartani egy ilyen helyzet megfelelő kezelésére alkalmas krízisforgatókönyvet. A második hullámot, ha lesz olyan, már egészen biztosan sokkal felvértezettebb állapotban várhatjuk mind szakmai, mind szervezettségi, mind pedig múszerezettségi szempontból. Fontos azonban annak a fogalomnak a pontosítása, hogy a „második hullám” azt jelenti, ahogyan ez a spanyolnátha esetében is történt, hogy egy kisfokban mutálódott vírus tér vissza ugyanabba a populációba, ahol már járt. Nem tekintheto” „második hullámnak", hogy mondjuk Wuhan helyett a 20 milliós Pekingben találnak néhány száz fertőzöttet, akik közül nem tudni, hogy mennyi a beteg. Hasonlóképpen a németországi húsüzemben talált 1500-at meghaladó tünetmentes fertőzött sem jelenti az ún. második hullámot, ez még mindig csak az első, ami nem múlott el. Ilyen esethalmozódásokra Magyarországon is számítani kell, ami nem jelent második hullámot és indokolatlan lenne bármilyen pánik keltése. Biztosak lehetünk abban, hogy a vírus velünk marad mindaddig, amíg hatékony védőoltás nem áll a rendelkezésünkre, ezért elsősorban az elérhető terápiás lehetőségeinket kell bővíteni azokban az esetekben, ha COVID-19-fertőzést észlelünk, de lehetőségként kínálkozhat a felnőtt lakosság önkéntes alapon történő MMR-újraoltása is.

Sajnos világszerte el kell gondolkodni azon, hogy mit tegyünk a tünetmentes vírushordozókkal, mivel nem lehet országokat, gazdaságokat lezárni, milliókat tartósan karanténba helyezni mindaddig, amíg a vírus el nem tünik (nem fog). Azt a kínos kérdést kell világosan tisztázni, hogy az eddigi gyakorlaton változtatva, csak a súlyosabb légúti panaszokat mutató betegekre koncentrálunk, és leteszünk a tünetmentes (vélhetôen sok millió) hordozók felkutatásáról, legfeljebb szeroepidemiológiai vizs- 
gálatokat végzünk az átfertőzöttség megál lapítására.

Confucius-idézettel kezdtük, azzal is fejezzük be: „A tigrist elöbb gondolatban kell elejteni - a többi csak puszta formalitás.”

\section{Irodalom}

[1] https://www.cdc.gov/flu/pandemicresources/1918-pandemic-hlnl.html

[2] Wang X, Li Y, O'Brien KL, et al. Respiratory Virus Global Epidemiology Network. Global burden of respiratory infections associated with seasonal influenza in children under 5 years in 2018: a systematic review and modelling study. Lancet Global Health 2020; 8: e497-e510

[3] https://www.cdc.gov/flu/about/burden/2018-2019.htm

[4] Tyrrell CSB, Allen JL, Carson G. Influenza and other emerging respiratory viruses. Medicine (Abingdon) 2017; 45: 781-787.

[5] https://theconversation.com/the mysterious-disappearance-of-the-firstsars-virus-and-why-we-need-a-vaccinefor-the-current-one-but-didnt-for-theother- 137583

[6] https://applications.emro.who.int/ docs/EMRPUB-CSR-241-2019-EN pdf $: u a=1 \& u a=1 \& u a=1 \& u a=1 \& u a=1 \&$ ua $=1$

[7] https://www.worldometers.info/coronavirus/

[8] https://www.worldometers.info/coronavirus/country/hungary/
[9] https://home.kpmg/xx/en/home/ insights $/ 2020 / 04 /$ ukraine-government-and-institution-measures-in-response-to-covid.html

[10] https://www.rki.de/EN/Home/ homepage.html

[11] Meenakshisundaram R, Senthilkumaran $S$, Thirumalaikolundusubramanian $P$. Protective effects of vaccinations and endemic infections on COVID-19: A hypothesis. Med Hypotheses 2020; 26 : 143: 109849.

[12] https://www.researchgate.net/publication/341354165_MMR Vaccine Appears_to_Confer_Strong_Protection from_COVID-19 Few_Deaths from_SARS-CoV-2_in_Highly_Vaccinated_Populations?channel=doi\&linkI $\mathrm{d}=5 \mathrm{ebc0220a6fdcc} 90 \mathrm{~d} 67350 \mathrm{c} 9 \&$ show Fulltext=true

[13] Qaseem A, Yost J, Etxeandia-Ikobaltzeta I, et al. Update Alert: Should clinicians use chloroquine or hydroxychloroquine alone or in combination with azithromycin for the prophylaxis or treatment of COVID-19? Living practice points from the American College of Physicians. Ann Intern Med. 2020 Jun 17. Doi: 10.7326/M20-3862. [Epub ahead of print]

[14] Fábián Á, László I, Juhász M, et al. Pharmacological options in treating SASR-CoV-2 infection/COVID-19. [Farmakoterápiás lehetôségek SARSCoV-2-fertőzés/COVID-19-betegség esetén.] Orv Hetil. 2020; 161: 685688. [Hungarian]
[15] Beigel JH, Tomashek KM, Dodd LE, et al. Remdesivir for the Treatment of Covid-19 - Preliminary Report. N Engl J Med. 2020 May 22. Doi: 10.1056/ NEJMoa2007764. [Published online ahead of print]

[16] Bobek I, Gopcsa L, Réti M. et al. Successful administration of convalescent plasma in critically ill COVID-19 patients in Hungary: the first two cases. [Az első két sikeres, convalescens friss fagyasztott plazmával történő terápia hazai alkalmazása intenzív osztályon kezelt, kritikus állapotú, COVID-19fertőzésben szenvedő betegekben.] Orv Hetil. 2020; 161: 1111-1121. [Hungarian]

[17] Lakatos B, Gopcsa L, Gondos E, et al. Anti-cytokine therapy in novel coronavirus disease (COVID-19) - the first administration of tocilizumab in Hungary at a department of infectology. [Citokinellenes terápia az új típusú koronavírus okozta megbetegedés (COVID-19) kezelésében - tocilizumab elsőként való alkalmazása egy hazai infektológiai osztályon.] Orv Hetil. 2020; 161: 1070-1077. [Hungarian]

[18] Gál J, Fülesdi B. The intesive care requires conceptional changes in Hungary. [Koncepcionális átalakulásra szorul a hazai intenzív ellátás.] Orv Hetil. 2011; 152: 94 [Hungarian]

Ternák Gábor dr. Fülesdi Béla dr.

\section{A rendezvények és kongresszusok híranyagának leadása}

a lap megjelenése előtt legalább 40 nappal lehetséges, a 6 hetes nyomdai átfutás miatt. Kérjük megrendelőink szíves megértését.

A híranyagokat a következő címre kérjük:

Orvosi Hetilap titkársága: edit.budai@akademiai.hu

Akadémiai Kiadó Zrt. 